\title{
FOREWORD TO THE SCOPE OF THE LABOR EXEMPTION IN PROFESSIONAL SPORTS: A PERSPECTIVE ON COLLECTIVE BARGAINING IN THE NFL
}

\author{
ED GARVEY*
}

The article by Professor Ethan Lock that I have been asked to introduce explains in detail the history of the long struggle between the National Football League Players' Association (NFLPA) and National Football League (NFL) owners in the courts and before the National Labor Relations Board (NLRB). The article also indicates how the labor-manageinent problems that have separated the two sides can be resolved. These problems can be cured if both sides: clearly recognize the realities of the caselaw established in the 1970s, examine carefully their own self-interest, and give at least a casual glance to the public's interest in finding a workable relationship. However, absent such a realistic assessment the battle will likely rage into the next decade.

To understand the current dispute in the NFL, Professor Lock provides a useful legal background, highlighting the history of player restraints in the NFL and the unique nature of collective bargaining in the context of the football industry. ${ }^{1}$ Professor Lock then suggests solutions which stem froin both our public policy toward labor-management conflicts, as embodied in the labor laws, and the public interest inherent in those conflicts. ${ }^{2}$ However, in order to appreciate and understand the current dispute, one inust grasp more than labor law principles and a vague sense of the public interest. Therefore, in the next several pages I will describe the third side of the framework-the perspective of the various interested parties in the dispute.

Bargaining in the NFL over a new collective agreement ceased Inonths ago. In Noveinber 1988, the NFL, through its bargaining arm, the NFL Management Council (NFLMC), announced that the League would implement a new "free agent" system on its own if the NFLPA refused to choose between two options drafted by the owners and their

Copyright $(9) 1989$ by Duke Law Journal

* J.D., University of Wisconsin. Executive Director, National Football League Players' Association, 1970-1983.

1. See Lock, The Scope of the Labor Exemption in Professional Sports, 1989 DUKE L.J. 339, 343-78.

2. See id., at $395-415$. 
attorneys. ${ }^{3}$ The union proposed a middle ground along the lines of the National Basketball Association and Major League Baseball solutions in which players have freedom to move but overall limits are placed on clubs. In response, management refused to compromise and instead announced in February, 1989, that it would implement its own version of a new reserve system tying players to their teams. ${ }^{4}$ The union opted to reject management's options, and instead will rely on an antitrust case pending in Minnesota district court ${ }^{5}$ to gain in court what they had little chance to achieve in collective bargaining-complete free agency for veteran NFL players. In the meantime, the complex NLRB case arising out of the NFL's alleged illegal activity during the 1987 negotiations, strike, and scab games inoves along with glacial speed. ${ }^{6}$ At this juncture it seein likely that the "greenhouse" effect will melt the polar ice caps before the NLRB disposes of the case.

With bargaining at an impasse, the players' union finds itself in a difficult position. The prevailing wisdom among players' agents is that NFL superstars will be better off if they can stop a collective bargaining agreement, or even a court settlement of the antitrust case, because implicit in a labor agreennent or a settleinent is the word "compromise." Compromise is required not just between managenent and labor, but also among members of the union. Under a negotiated settleinent, the stars would have to take less so the defensive backs, punters, and lineinen can get a little more.

The agents assume that a finite pot of money is available each year for players' salaries, and if the stars get more, the rest get less. Under this scenario, the stars have individual bargaining power, but the nonstars must depend on collective bargaining for most of their salary and benefits. While current NFLPA leaders discredit that approach because it has been proven wrong in baseball, it has credibility in the sports press and among agents because NFL management repeats it all the time: "If the stars have unlimited freedom of movement, there will be no money left for the non-stars."

If the agents who represent superstars succeed in decertifying the union, as some are attempting to do, it should be clear that without a union the agents would never reach an agreenent with the NFL. One reason is that they are confident that NFL owners will never agree voluntarily, in a collective bargaining agreement, to free agency-and they may be right. With no agreenent, the agents would operate in their ideal

\footnotetext{
3. See id. at 347.

4. See id.

5. Powell v. NFL, 678 F. Supp. 777 (D. Minn. 1988).

6. NLRB Memorandum Case No. 2-CB-12117.
} 
situation of negotiating everything: salary, pension, insurance, and postseason pay. Today, agents negotiate only regular season pay; the union takes care of the rest. ${ }^{7}$ Curiously, the management people who support the decertification effort have not figured out a game plan yet. They operate on the philosophy, "If my enemy is unhappy, I am happy." And, it is clear that the decertification effort, while not a serious threat, is a time consuming annoyance that distracts and unsettles the NFLPA leadership.

Given the ease with which the NFL crushed the union's 1987 strike, ${ }^{8}$ an obvious mismatch at the bargaining table exists. In such a mismatch, I do not believe that there can be "arm's-length, good faith collective bargaining." 9 Future courts must look behind any agreement to determine whether there really was bargaining, or whether the NFL monopoly forced an agreement on a weak union..$^{10}$ Never again can there be an assumption of roughly equal strength when reviewing player restraints in the NFL.

Frankly, an agreement in the next two or three years is unlikely. If the union could shut down the Super Bowl or the playoff games, the parties would reach an agreement immediately. Everyone knows that, and everyone also knows that the union lacks such power. Unless the union can apply econoinic pressure on management, management will not engage in meaningful arm's-length bargaining.

In fact, bargaining as such inay be dead in the NFL. My reasons for despair can best be illustrated by presenting the hypothetical views, in their own words (more or less), of the various participants in this gamethe owners, the union, and players' agents. I choose this approach because it is the attitudes of these participants that lead to law suits, NLRB complaints, strikes, congressional hearings, elaborate preparations for labor war with no effort to achieve labor peace, scab games, and law review articles. Let us begin this examination with a hypothetical look at manageinent's side through the eyes of a hard-line advisor.

This manageinent advisor would tell the NFL owners that an agreement is unlikely for several reasons. The archetypal management advisor

7. The 1982 Collective Bargaining Agreement Between the National Football League Management Council and the National Football League Players' Associâtion covers, inter alia, meal allowances, $i d$. art. XXV; moving and travel expenses, id. art. XXVII; group insurance, id. art. $\mathrm{XXX}$; and a retirement plan, id. art. XXXIV.

8. See Lock, supra note 1 , at 367.

9. See Mackey v. NFL, 543 F.2d 606, 614 (8th Cir. 1976) (labor exemption applicable only where the agreement sought to be exempted is the product of bona fide, arm's-length bargaining), cert. dismissed, 434 U.S. 801 (1977).

10. For a discussion of the inequality of bargaining power in NFL-NFLPA negotiations, see Lock, supra note 1, at 354-59. 
would make the following argument: "First, there is no reason for management to want an agreement with the union. We are doing just fine. Money is pouring in, our hidden wage scale with its consistent level of salary increases continues to hold expenses in line, ${ }^{11}$ and we are about to stop paying the bills for the pension, insurance, and severance pay benefits just as we prepare for our first significant cable television package deal. When we cut out all collective benefits, we will have wiped out twenty years of union progress, and we will be back where we started in 1970 after the AFL-NFL inerger-no collective benefits and no free agency. The union will have to scratch and claw its way back to where it was in 1987." He would add: "The agents are keeping the umion off balance, the reserve system is in place, the NLRB will never do anything, and the courts are so slow and judges so timid when sports are involved that it will be busimess as usual for the foreseeable future."

Our management advisor would continue: "Second, even if for some reason you wanted an agreement, the union is in no position to extract sufficient concessions from you to convince its members to agree. You have them right where you want them. You have successfully convinced a majority of players that the NFL is so powerful that the players cannot strike. The horrendous 'replacement' games were covered by the networks, and some announcers even started babbling that the scabs were almost as good as the regulars! I don't know how you forced the networks to cover the worst football ever aired, but it worked. People watched, advertisers paid, and the strike collapsed. The players know they cannot strike effectively."

This hard-line advisor then would make his final point: "Third, the group seeking decertification of the NFLPA is destabilizing the situation just enough so that the union leadership can't spend all its efforts building strength for a fight with us-they must fight the new group. If they compromise on free agency, the agents will argue that the union leadership 'sold out' the membership. In fact, if they get anything less than a perfect agreement, the leaders will be thrown to the proverbial dogs by agents, sports writers, and stars. And, let's face it, you have no need to ever agree to their idea of a 'good deal,' let alone a great deal. The essence of an agreement in labor is compromise, and since free agency is the only issue on the table in the minds of the players and the public, compromise is impossible. Either you are free or you aren't. Anything less than complete freedom will be regarded by the players as a loss because it will be played in the nredia as the only important issue. ${ }^{12} \mathrm{My}$

\footnotetext{
11. See. NFLPA, STAT SHEET (Winter 1988-89) (consistent pattern of increases in average NFL salary).

12. See, e.g., Scorecard, SpoRTS IllustraTed, Feb. 13, 1989, at 7-8.
} 
conclusion is that you will not get an agreement in the next year and maybe you will never have an agreement with the NFLPA again, so relax."

An equally astute advisor on the umion side would tell the Board of Player Representatives, the governing body of the union, that a number of factors will prevent the parties from reaching an agreement. The union advisor will tell his story thus: "First, the owners are not unified enough to accept free agency in a collective bargaining agreement because they are afraid that one or two owners night actually bid on free agents and thus expose the quiet conspiracy that has been part of the NFL smce the 1920s. The quiet conspiracy works so long as there is a public excuse not to bid for players. For a while it was the Rozelle Rule; now it is the riglit of first refusal/compensation system. ${ }^{13}$

"Prior to the Mackey v.NFL case settlement in 1976,14 teains said they would not sign veteran free agents because they feared the compensation to be set by Conimissioner Rozelle might be another veteran player; they suggested that if it were only a draft choice or two, they would be happy to sign a first-rate, proven veteran. ${ }^{15}$ Then in 1977 the union and the owners reached a settlenient that was supposed to bring about significant bidding for free agents because it elininated the worst aspects of the old Rozelle Rule. Under the 1977 plan, no veterans could be used as compensation, the Commissioner would be removed from the systen, and the conipensation would be established in advance to remove the fear of the unknown. ${ }^{16}$ But as soon as the ink was dry, team owners refused to sign proven veteran free agents. There was no movement of players and no bidding for their services despite all the proinises in bargaining and to the court. ${ }^{17}$ One excuse was that the owners now feared the 'known' use of draft choices as compensation for veteran free agents. The fact is, they have used available excuses for sixty-eight years. Court decisions, strikes, and NLRB rulings aside, the owners have never bid for free agents in the NFL."18

The union advisor would add: "Besides, we all know that coinplete free agency niay not work even for the stars because there is no economic incentive, given the corporate socialism of the NFL owners, for a team to

13. For a discussion of the history of various forms of player restraints, see Lock, supra note 1 , at $346-47$.

14. See id. at 379-81 (discussion of Mackey).

15. For a discussion of the Rozelle rule and its impact on player movement, see id. at 348.

16. See id. at 359-61.

17. See id.

18. For a discussion of the history of restraints on player movements, see id. at 346-47. 
spend the necessary money to sign a free agent. ${ }^{19}$ But if all the excuses were eliminated, and still no free agents were signed, the conspiracy would be so obvious that litigation would surely follow. Losing owners would have no excuse not to sign a star free agent. The fans would begin to catch on to the real game of football played by the owners. Now clearly most objective observers would say that twenty-eight owners, operating within a monopoly where most revenues are shared equally, would never bid against one another-but stranger things have happened. With new owners coming into the League, one or two might break the unwritten rule and try to buy enough talent to win. Either way, free agency poses some risk for the owners."

The union advisor would continue: "Second, the owners have put in place a mechanism in the NFL constitution and by-laws to protect the hardliners against owners who want labor peace. The hardhiners need but seven votes to block any agreement with the union. ${ }^{20}$ When the National Labor Relations Act was passed, Congress never contemplated an unregnlated monopoly with a built-in minority control mechanism negotiating with a union. While the NLRB has ruled that extraordinary majorities in multi-employer bargaining units are acceptable and legal, ${ }^{21}$ the NFL presents a special case. In the normal multi-employer bargaining unit, each member can withdraw from the unit before bargaining with the union cominences. Unilateral withdrawal is unavailable in the NFL, however, as it takes a constitutional amendinent to allow a team to withdraw from the multi-enployer unit and negotiate individually. ${ }^{22}$ Once again, seven owners could stop either from happening. As a result, the NFL cannot be treated like any other enployer. The 'tyranny of the minority' among NFL owners will prevent any agreenient in the NFL until Congress takes a look at the monopolistic monster it created (by giving the NFL two statutory exemptions from the antitrust laws ${ }^{23}$ ), or until the courts rule that the nonstatutory labor exeniption is inapplicable if a minority controls the managenient side."

19. Corporate socialism results from the NFL's broadcasting revenue sharing plan in which all teams receive a pro rata share of the networks' payment, which represents by far the largest source of NFL revenues. See id. at 405 (discussion of pro rata plan and resulting lack of intra-league competition).

20. NFL Const. and By-Laws.

21. Cf. In re Shipowners' Ass'n, 7 N.L.R.B. 1002 (1938) (multi-employer association, acting on behalf of individual employers for collective bargaining, was within definition of "employer" under the Wagner Act and its employees constituted appropriate unit).

22. NFL Const.

23. 15 U.S.C. § 1291 (1982); See Lock, supra note 1, at $402-16$ (discussing NFL's statutory exemptions). 
Finally, our advisor might say: "We have only three possibilities: 1) we must win the antitrust case and get free agency for all players; 2) Congress must reexamine the statutory antitrust exemptions; or 3) another league must start to give players a choice. ${ }^{24}$ When there is competition between leagues, the NFL will quickly settle differences with the players in order to get on with the all important task of maintaining monopoly status."

The agent advisor, speaking to those involved in the union decertification effort, explains that perspective. He begins: "We must stop a collective bargaining agreement at all costs. Threaten decertification to keep the NFLPA off balance, tell your people not to pay dues and blame the union leadership for inanagement's power in breaking the strike in 1987.25 And, if they try to settle the Powell case, ${ }^{26}$ we will be there in force to object to any settlement that restricts, in any way, movement of veteran free agents. Furthermore, we inust stop any agreement between the union and the NFL that would allow the common draft of rookies to continue. If we can abohish the draft, that will mean more money for our players so salaries will go up dramatically without an agreement. Remember, the more division among the players, the less consensus exists for an agreement."

These differing viewpoints illustrate just how far apart the parties are in this dispute. As I see it, in order to reach a workable level of understanding and labor peace, each of the parties needs to confront the following realities:

1. The League needs an agreement with a strong union to operate effectively without crippling lawsuits and without domination of the game by a few agents representing a handful of superstars.

2. Without the athletes there is no football industry. They are the reason why people watch the game, and there is no point in continuing efforts to beat them. The NBA and its union work together, with the players benefiting from a minimum of $53 \%$ of gross revenues, free agency, and stability. ${ }^{27}$ The NBA plan is based on the 1982 NFLPA negotiating position, and it works. The NFL needs a labor-management partnership along those same lines.

3. The only justification for the draft, standard player contract, option clause, and reserve system is that a strong union accepted those restrictions as a compromise to achieve the greater good for the greatest number of players. If any restrictions are forced upon a weakened

24. For a discussion of measures which can be taken to right the current imbalance in the NFL, see id. at $395-419$.

25. See id. at 367.

26. Powell v. NFL, 678 F. Supp. 777 (D. Minn. 1988).

27. See Lock, supra note 1 , at 341 \& n.15. 
union, those restrictions are bound to eventually fail the Mackey test. ${ }^{28}$ The NFLPA engages in collective bargaining, not individual bargaining. The test of its duty of fair representation is how well all players do under an agreement, not just whether a few at the top of the salary range do well. ${ }^{29}$

4. For management to attempt to justify restrictions on bidding for veteran athletes within a monopoly on the grounds that it saves the monopoly money, or that free agency will "destroy the NFL as we know it today," is absurd on its face. Every court looking at those arguments has said so, ${ }^{30}$ and every court im the future will follow that reasoning. The sooner the owners face that fact, the sooner there will be peace.

5. The focus of the current dispute is, as usual, too narrow. A collective bargaining agreement provides, inter alia, for pensions, severance pay, an effective grievance system to settle disputes, benefits to injured players and widows' benefits, and guaranteed contracts-much more than just free agency. But many of the sports columnists seem incapable of focusing on a variety of issues, so they focus exclusively on "free agency."

In my view, the emphasis is all wrong. In 1974, the union went out on strike over the "freedom" issues, i.e., the union wanted to end the reserve system. In the process it found out how powerful and obstinate the NFL can be. But in 1974, I can tell you that the union's emphasis was on freedom and dignity for all players, not more money for the stars. Somehow, though, the press focused only on money rather than dignity. The goal was a stronger union of free men who could gain more collective benefits, not secure millions for a handful of superstars, but the press and the public missed all that.

On the free agency issue, the NFL has split the players into haves and have-nots. They obfuscated the human issues by emphasizing the economic issues. It was simply divide and conquer. The original message to the linemen was: "Are you really on strike so quarterbacks can get more money? I thought you were smarter than that, son. We won't bid for you. We will bid for the quarterbacks, and when we do, there won't be any money left in the pot for you. It's none of my business because its your union, but if I were you, I'd get my fanny into camp before that good-looking rookie beats you out of your job."

Today, the NFL is sending a different message to that lineman: "You must choose between collective benefits, mcluding the pension, and free agency. Unless you give up your demand for freedom at the table, we will punish you by eliminating all collective benefits." But circumstances today are much different than they were in 1974 or even in 1982 . In 1974 , the average salary was $\$ 33,000$, and by 1982 it had

28. See Mackey v. NFL, 543 F.2d 606, 615-16, (8th Cir. 1976) (labor exemption does not apply to Rozelle Rule where no bona fide arm's-length bargaining took place), cert. dismissed, 434 U.S. 801 (1977).

29. R. Gorman, Basic Text ON LABOR LAw 381, 695-98 (1976).

30. See Lock supra note 1 , at 359 \& $\mathrm{n} .114$ (discussing player restraint cases). 
only risen to $\$ 102,500 .^{31}$ Even in 1982 , fringe benefits were extremely important as a percentage of the players' economic package. Today, with the average salary at nearly $\$ 250,000$, fringe benefits, although high by most standards, make up less than $25 \%$ of the players' economic package. ${ }^{32}$ In my view, the threat to "cave in or lose your benefits" will work because salaries are so high and benefits hold less significance.

Management had a lot more difficulty dividing the players in 1982 than in 1974 because in 1982 the union went for money for all players. The goal was not money that might result from an untested theory of free agency and "trickle down" economics, but actual dollars for severance pay, insurance, pensions, and a wage scale. In 1974, the NFL broke the strike with raw power, some illegal actions, and superior resources. ${ }^{33}$ Management said they were fighting the union to protect the reserve system. In 1982, eight games were cancelled and the season was one week from cancellation because the players were united as never before over collective money issues at a time when individual negotiations had not resulted in high wages. All that is changed today.

6. The NFL owners will keep the focus on their refusal to agree to complete free agency in order to keep the focus off the real money issues. And the sports media will judge every offer by comparing it to free agency in basketball and baseball, not by comparing the more significant statistic of the percentage of gross revenues going to athletes in the various leagues. Prior to the 1982 collective bargaining agreement, players were receiving roughly $30 \%$ of gross revenues. Today the NFL estimates that players are getting $65 \%$ of gross, which would make it higher than that dedicated to players in the NBA. ${ }^{34}$

Free agency, even if granted, will not, in my opinion, significantly improve the lineman's salary or benefits, although the average NFL salary would rise as teams signed free agent superstars. The reason is that the owners will continue wherever possible the quiet conspiracy to hold down wages. They can do that easily with offensive linemen, kickers, defensive backs, but not so easily with the quarterbacks, receivers, and running backs. My view is that the union should deemphasize free agency and refocus on agreement over a fixed percentage of gross revenues, especially as the NFL marches toward pay-per-view telecasts of its games. But the genius of collective bargaining is that it changes with each new group; it is no longer up to me and the players of the 1970s.

31. NFLPA, STAT SHEET (Winter 1988-1989).

32. Id.

33. See generally Lock supra note 1, at 359-60 (owners dominated union in 1974 negotiations despite union's use of every possible legal and economic weapon).

34. The NFL owners, of course, have a stake in exaggerating the percentage to show they cannot afford free agency, but union leaders generally believe that the players are getting at least $55 \%$. 
Today's posture must reflect the change in circumstances. If the membership thinks free agency is the key issue, they should pursue it.

In a real sense, unfortunately, all of this debate may not really matter. Simply put, the NFL is too powerful for the union to gain significant changes through negotiations in free agency or a fixed percentage of the gross. Collective bargaining is being strangled to death because the NFL monster got too big and too strong. They control the networks; they control the announcers; they have most of the sports press on their side; and more important than anything else, because they operate as a monopoly sharing everything, they have money and time on their side.

To suggest that the NFL, a monopoly that has systematically destroyed all competitors for major league football in this country ${ }^{35}$ and has secured two antitrust exemptions froin Congress, ${ }^{36}$ should now be allowed to argue that their unilaterally imposed system to stop themselves from spending more money on talent should be protected under labor's exemption to the antitrust laws even after an agreement expires, is ridiculous. The owners seek to claim the benefit of the labor exemption while the League is doing everything in its power to break the union, and while they refuse to bargain in good faith for a new agreement. It is "Boulwareism" with a vengeance. ${ }^{37}$ It would be turning a blind eye to reality for courts to ignore the bargaining history between this union and this monopoly and conclude that there should be an exemption to patently illegal contracts and combinations in restraint of trade. The simple presence of a union cannot change the picture. The union cannot effectively strike. Therefore, the union cannot make meaningful demands, let alone engage in meaningful arm's-length bargaining. An "arm's-length, good faith collective bargaining agreement," the yardstick applied by the Mackey court, is almost out of the question. If a court were to hold that the NFL can rest easy under the labor exemption, which comes from an "agreement" in which players accept, if not propose, certain restrictions, then courts and Congress have really done more for football owners than the Supreme Court ever did for baseball owners. ${ }^{38}$ One would only hope that the name is changed to "manage-

35. NFL v. USFL, 644 F. Supp. 1040 (S.D.N.Y. 1986) (finding NFL had monopoly power in professional football market), aff'd, 842 F.2d 1335 (2nd Cir. 1987).

36. 15 U.S.C. $\$ 1291$ (1982); See Lock, supra note 1, at 402-15 (discussing NFL's antitrust exemptions).

37. See General Elec. Co., 150 N.L.R.B. 192, 196 (1964) (celebrated case in which GE vicepresident utilized strategy of going over heads of union leaders directly to membership on "fair, firm" offer; Board found actions not bargaining in good faith). See generally H. NORTHROP, BoulWAREISM (1964) (discussing General Electric and management strategy of merchandising offer directly to union members and public).

38. See Flood v. Kuhn, 407 U.S. 258 (1972) (reaffirming baseball's antitrust exemption). 
ment's exemption" to be invoked whenever a monopoly rolls over a union.

What is the solution? Read Professor Ethan Lock's article and see how Congress or the courts can solve the problems for two parties who refuse to recognize reality, either legal or economic. The participants who benefit from this stalemate are the superstars, agents, and owners. The losers are the non-star players who make up about $96 \%$ of the union. These players face real hardship: they have no job security because they can be fired at any time; they are frequently cut when they get injured, but face delay in getting an arbitration decision; their pensions are in jeopardy; and their salaries are depressed by the reserve system. ${ }^{39}$

Sensible people could settle this dispute quickly, but the owners seem caught up in the contest. They may have forgotten why they started this game. Was it to finally get back at the union for 1982? Are they still angry with John Mackey? Did they decide that once and for all they would show those jocks who is in charge? Are the NFL attorneys intent on re-trying the Mackey case? Probably all of the above, although in my opinion none of the above justifies the risks involved in letting the lawyers call the plays. It is time for a settlement. If none comes, it is time for the solutions outlined by Professor Lock.

39. See, e.g., NFL Standard Player Contract 1011 (rev. 1982) (players can be cut at any time). 